\title{
Building Students' Characters by Habituation of Practicing Hadith Using Star Calendar Media
}

\author{
Rizka Harfiani \\ Student of Doctorat Program, University of Muhammadiyah Malang, \\ Lecture of University of Muhammadiyah Sumatera Utara, Indonesia \\ rizkaharfiani311@gmail.com
}

\begin{abstract}
The objective of this research is to build students characters at Ar-Rasyid Islamic Primary School located at Sukamaju Village, Deli Serdang Regency, North Sumatera. The research used Class Action Research with the qualitative approach and type of case study. The research subjects were 20 students grade $2 \mathrm{~B}$. The data were gathered by conducting observation, interviews and documentation as recording used star calendar media. Data analysis techniques have done descriptively. The research based on first researcher observation, that $90 \%$ of students grade 2B had no good character yet, so the researcher attempts to build students characters by habituation of practice hadith. The result of this research can be stated that buildingstudents characters by habituation of practice hadith using star calendar media at Ar-Rasyid Islamic Primary School was success and students characters increased with a very high category.
\end{abstract}

Keywords: students character; the practicing hadith; star calendar media

\section{INTRODUCTION}

The children are very important infestation for the future human resource setup. Paying attention to the children to get the education, especially the character building, is one of the ways to prepare supreme generations for the nation's progress. The character building at the school is very needed, the characters could be improved by learning experience and learning process and finally will build students characters.

Study of various character building approaches, based on discussion result with the teachers and practical reasons in its use in the area, are summarized into five typology approaches, there are (1) inculcation approach, (2) cognitive moral development approach, (3) values analysis approach, (4) values clarification approach, (5) action learning approach[1].

To be effective and intact, the character building must enclose three bases in its programming. Without that three bases, the program of character building at the school is just the opinion only. First, the character building based on classroom design. This design based on the relation of the teachers and the students as the learners in the classroom. The character building context is the relational process of classroom communities in the learning context. Second, the character building based on school's culture design. This design tries to build a capable school's culture of building students characters with school's social agency assistance in order to be formed a certain value and to be embedded in students. Third, the character building based on community design. In educating, school's communities are not fighting alone. The community outside the school, such as family, general community, and the country, have a moral responsibility to integrate character building in their life context[2].

How important the character building at the school in the building students characters, gets me interested to make research at the Private Islamic Primary School that try to build students characters by habituation of practice hadith used star calendar media.

Allah SWT had prepared Prophet Muhammad SAW with honorable characters before he became the prophet. Allah SWT tell us to follow Prophet Muhammad SAW characters[3]. Allah SWT says in Surah Al-Ahzab/33:21, "Verily in the messenger of Allah you have a good example for him...". So that learning hadith is important to do, in order to embed the Rasulullah's characters to students characters.

The main purpose of sending Rasulullah is to improve the characters. The character building concept has long been created by Rasulullah through his hadith which very important to be improved and learned. The quality education theory is the right theory logically and based on Al-Qur'an and Sunnah. How does Al-Qur'an and hadith build the character building? An interesting concept about the character building in Islam is Tadzkirah. Tadzkirah is an example, impulse, referrals, zakiyah, continuously, remind, repetition, coordination, and heart[4]-[7].

Building students characters at the Islamic schools needs deep analysis between approaches and right learning strategies. And create an integrated system of Islamic education to prepare Islam's generation in the future[8], [9]

\section{METHOD}

The research held at Primary SchoolAr-Rasyid, located at SukaMaju Village, Sunggal Subdistrict, Deli Serdang Regency, in the academic year of 2017-2018. The research subjects were a teacher and 20students grade 2B: 14 male students and 6 female students.

The research uses a descriptive method which described a condition or phenomena in the field during the process of the research. It also used Class Action Research[10], which had four main principles which indicated the stages: planning, implementing, observing, and reflecting.

Class action research is a research which provides activities for the research objects with sustainable cycles until the goal of the research is achieved. The procedure of precycle action was described in the recycled scheme as Picture 1. 


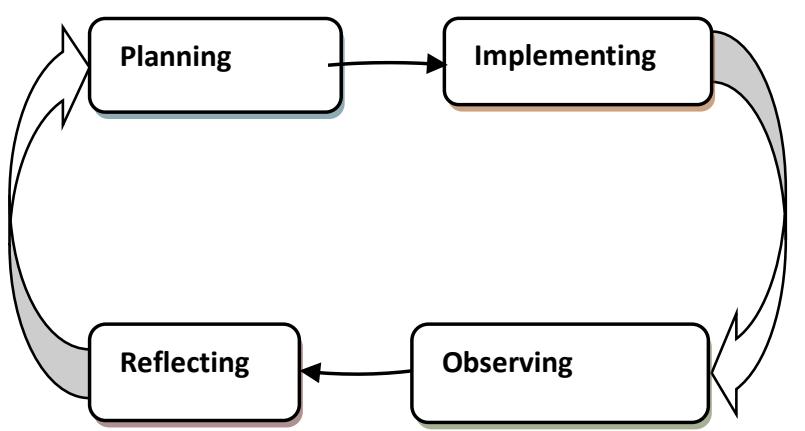

Picture 1. Cycle Scheme of Class Action Research

The data were gathered by conducting interviews, observation, and documentary study. In the class action research implementation, there were qualitative data and quantitative data.

The data of the research result would be analyzed by using the scale of the development achievement which determined the children's development by the end of the assessment period[11]. There were four scales used in the research:

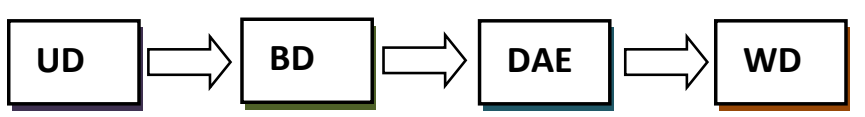

Picture 2. The scale of the Achievement of Children's Development

\section{UD: Undeveloped}

It indicated that the child did not show good character

\section{BD: Began to Develop}

It indicated that the child began to show good character even though he was still reminded and guided by his teacher.

DAE: Developed According to Expectation

It indicated that the child showed good character consistently and full of awareness, without being reminded by his teacher.

WD: Well-Developed

It indicated that the child had shown good character consistently and was willing to guide his friends in implementing good character according to the expected indicator.

This research used action cycles by comparing the result before and after the treatment of the research objects. The purpose was to build students characters by habituation ofpractice hadith usingstar calendar media at Ar-Rasyid Islamic Primary School. Some attitudes that be evaluated are friendly, kindly, patient, forgiving, diligent, obedient to the teachers, well mannered and accustomed to say good. The teaching planning included introduction activity, core activity, and closing activity.Every day, the teacherevaluates students attitude improvementwith star calendar media.Star code could be seen in Table 1 .
Table 1. Star Code

\begin{tabular}{ll}
\hline Code & Scale \\
\hline$\star \star \star$ & Undeveloped (UD) \\
$\star \star \star \star$ & Began to Develop (BD) \\
& $\begin{array}{l}\text { Developed According to Expectation } \\
\text { (DAE) }\end{array}$
\end{tabular}

Well-Developed (WD)

The formula used to find out the increase students characters were:

Percentage Grade $=$ Number of Scores Earned/ Number of Children x $100 \%$

The procedure of class action research was realized in some cycles so the teaching goal was achieved according to what had been expected which indicated that the research (cycles) would be terminated when the teaching goal had been achieved. This research would be terminated when the result of the children's achievement in the categories DAE and WD had surpassed $95 \%$.

The presentation of data exposure was described in summary about what had been done by the researcher since the initial observation (initial condition of the teacher and students), in the initial reflection as the basis for the next plan with the exposure about the action implementation, the result of interviews, the result of the observation of the children, the observation on the class condition, and all of them were summarized to become the research findings.

\section{RESULT}

The attempt to build students characters in Ar-Rasyid Islamic Primary School, the teachers use star calendar media to evaluate students attitude improvement. Some attitudes that be evaluated are friendly, kindly, patient, forgiving, diligent, obedient to the teachers, well mannered and accustomed to say good. After the teacher gives the reinforcement in initiating the hadith learning, the students are asked to memorize the hadith by using the movement method, so that students more easily understand the meaning contained in the hadith and can be applied in everyday life.Every Friday, the teacher calculates the number of stars on the star calendar media. Students who get the highest number of stars will get the reward from the teacher as a form of appreciation for the character of students who are praised, but it also aims to motivate other students to have a good attitude. Over time, if a commendable character has been formed, then the reward is discontinued. And students have felt Ihsan, that God would watch over their actions and words.

The results of research ranging from pre-action, the first cycle, the second cycle, the third cycle, and the fourth cycle, from the raw data of students who obtained from classroom teacher grade 2B Ar-Rasyid Islamic Primary School at media star calendar, visible improvement by counting the number of stars as a value. 
Table 2. Data showing the number of stars on the teachers' assessment of student character

\begin{tabular}{ccccccc}
\hline No & $\begin{array}{c}\text { Research } \\
\text { Subjects }\end{array}$ & $\begin{array}{c}\text { Pre } \\
\text { Cycle }\end{array}$ & $\begin{array}{c}\text { Cycle } \\
\text { I }\end{array}$ & $\begin{array}{c}\text { Cycle } \\
\text { II }\end{array}$ & $\begin{array}{c}\text { Cycle } \\
\text { III }\end{array}$ & $\begin{array}{c}\text { Cycle } \\
\text { IV }\end{array}$ \\
\hline 1 & AQ & 1 & 2 & 3 & 2 & 3 \\
2 & AY & 2 & 2 & 3 & 4 & 4 \\
3 & BS & 1 & 2 & 2 & 3 & 3 \\
4 & CD & 2 & 3 & 3 & 4 & 4 \\
5 & DN & 1 & 2 & 3 & 3 & 3 \\
6 & DW & 1 & 2 & 3 & 3 & 3 \\
7 & EM & 2 & 3 & 4 & 3 & 4 \\
8 & FR & 1 & 1 & 2 & 3 & 3 \\
9 & FZ & 2 & 1 & 2 & 3 & 3 \\
10 & FC & 2 & 3 & 4 & 4 & 4 \\
11 & LV & 2 & 3 & 4 & 3 & 4 \\
12 & IH & 1 & 2 & 3 & 3 & 4 \\
13 & MR & 1 & 4 & 3 & 4 & 4 \\
14 & NZ & 2 & 3 & 3 & 4 & 4 \\
15 & NJ & 2 & 4 & 3 & 3 & 4 \\
16 & RF & 2 & 4 & 4 & 4 & 4 \\
17 & ST & 2 & 3 & 3 & 3 & 4 \\
18 & SL & 2 & 3 & 4 & 4 & 4 \\
19 & TJ & 1 & 2 & 3 & 3 & 3 \\
20 & ZR & 2 & 4 & 4 & 4 & 4 \\
\hline
\end{tabular}

From the data, it can be recapitulated as follows:

Table 3. Recapitulation of data and percentage value improvement of student character

\begin{tabular}{ccccccc}
\hline No & $\begin{array}{c}\text { Research } \\
\text { Subjects }\end{array}$ & $\begin{array}{c}\text { Pre } \\
\text { Cycle }\end{array}$ & $\begin{array}{c}\text { Cycle } \\
\text { I }\end{array}$ & $\begin{array}{c}\text { Cycle } \\
\text { II }\end{array}$ & $\begin{array}{c}\text { Cycle } \\
\text { III }\end{array}$ & $\begin{array}{c}\text { Cycle } \\
\text { IV }\end{array}$ \\
\hline 1 & UD & 8 & 2 & - & - & - \\
& & $40 \%$ & $10 \%$ & - & - & - \\
\hline 2 & BB & 12 & 7 & 3 & 1 & - \\
& & $60 \%$ & $35 \%$ & $15 \%$ & $5 \%$ & - \\
\hline 3 & DAE & - & 7 & 11 & 11 & 7 \\
& & - & $35 \%$ & $55 \%$ & $55 \%$ & $35 \%$ \\
\hline 4 & WD & - & 4 & 6 & 8 & 13 \\
& & - & $20 \%$ & $30 \%$ & $40 \%$ & $65 \%$ \\
\hline \multirow{4}{*}{ Total } & 20 & 20 & 20 & 20 & 20 \\
& & $100 \%$ & $100 \%$ & $100 \%$ & $100 \%$ & $100 \%$ \\
\hline
\end{tabular}

Based on the results of classroom action research conducted, it appears that the change in the character of the students towards a better direction is shown on the number of stars on the star calendar which is the grade teacher's assessment is increasing (increasing in number). And the percentage of WD value is also increasing.

Results on pre-action of character formation of students have not developed. Then on the cycle I increased to $55 \%$, on the cycle II increased to $85 \%$, on the cycle III increased to $95 \%$, and on the cycle IV has reached $100 \%$. This increase occurred due to several factors, namely:

First, planning. A good planning determines a successful learning. After conducting reflection in pre-cycle and finding the low level of good character showed by research subject, a learning plan of hadith memorization then was arranged by using six simple hadith, namely:
1) Hadith about Smile: "Tabassumuka fii wajhi akhiika shodaqoh"

$$
\text { تبسمك في وجه أخيك صدقة رو اهالترمذي }
$$

"Your smile in front of your brothers is alms" (HR. Tirmidzi) Hadith Arbain Imam Nawawi

2) Hadith about Saying, Salam: "Afsyus salaam bainakum tahaabbuu”

$$
\text { أفثوا السلآم بينكم تحا بوا رواهالحاكم }
$$

"Spread the salam amongst you undoubtedly you will love each other" (HR. Hakim)

3) Hadith about Saying the good word: "Al kalimatuth Thoyibatu Shodaqoh"

$$
\text { الكلمة الطيبة صدقة رواهمسلم }
$$

"The good word is alms" (HR. Muslim)

4) Hadith about Loved: "Man laayarham laayurham" من لآ يرحم لاَ يرحم رواه منفقعليه

"Whoever does not love, will not be loved" (HR. Muttafakun Alaihi)

5) Hadith aboutDo not get angry: "LaataghdhobwalakalJannah"

$$
\text { لا تغضب ولك الجنَّة ر رواهالطبر انى }
$$

"Do not get angry and paradise will be yours" (HR. Thabrani)

6) Hadith about Be patient and forgiving: "Afdholul iimaani Ashobru was samaahah"

$$
\text { اً فضل الإيمانالصبرو السماحةزو اهالبذاري }
$$

"The ultimate faith is patience and forgiveness." (HR. Bukhori)[12]

All six hadith were read aloud by the teacher and followed by students in opening activity, main activity, and closing activity. The teacher also planned a learning model which was suitable to students' condition so the expected objective could calendar media at Ar-Rasyid Islamic Primary Schoolis categorized as very good.

Second, implementation. The implementation of actions should support the achievement of research objective. The teacher used movement and storytelling method in memorizing hadith. Thus, students could become more enthusiastic in the process of learning. Consequently, internalization of Rasulullah saw morals, a name well character can be applied by students in their daily lives. From the result obtained, it can be stated the implementation of action tobuild students characters by habituation ofpractice hadith used star calendar media at Ar-Rasyid Islamic Primary Schoolis categorized as very good.

Third, evaluation (result). The result of this research has achieved the expected objective and has answered research problems. Therefore, it can be stated thatbuilding students characters by habituation ofpractice hadith using star calendar media at Ar-Rasyid Islamic Primary School wassuccess and students characters increased with a very high category. 


\section{CONCLUSION}

In general, based on the result of this research, can be concluded that on pre-cycle, studentscharacter formationhave not developed, then on the cycle I increased to $55 \%$, on the cycle II increased to $85 \%$, on the cycle III increased to $95 \%$, and on the cycle IV has reached $100 \%$ which is the highest increase.

The learning plantobuild students characters by habituation ofpractice hadith using star calendar media at ArRasyid Islamic Primary School is categorized as very good which means learning plan has been arranged in accordance with research objective and has followed correct planning steps. The learning implementation to build students charactersby habituation ofpractice hadith is categorized as very good, which means lesson has conducted in accordance with learning plan and movement method is a very good method used in the process of character internalization for childhood. The result of this research can be stated that buildingstudents characters by habituation ofpractice hadith using star calendar media at Ar-Rasyid Islamic Primary School was success and students characters increased with a very high category.

The Researcher suggests movement method can be used in memorizinghadith and the method of telling stories about Rasulullah saw should be given in advance to give them understanding. It can establish students character and behavior, it is used in everyday life, it instills moral conduct, and it can be understood easily. Hadith memorization learning can become one of the ways to increase students character education. Therefore, teachers should be able to develop and apply hadith learning well and regularly accompanied by good examples of attitudes and behaviors.

\section{REFERENCES}

[1] Superka, A Typology of Valuing Theories and Values Education Approach-es, University of California, 1973.

[2] M. Muslich, Pendidikan Karakter Menjawab Tantangan Krisis Multidimensional. Jakarta: Bumi Aksara, 2011.

[3] R. Megawangi, Belajar dari Keteladanan Akhlak Muhammad SAW. Depok: Indonesia Heritage Foundation, 2015.

[4] A. Fattah, "Konsep Pendidikan Karakter dalam Perspektif Hadis," J. Tarbawi, vol. 1, no. 2, pp. 113122, 2017.

[5] G. Cahyono, "Pendidikan Karakter Perspektif AlQur'an dan Hadits," Al-Astar J. Ahwal Al-Syahsiyah dan Tarb. STAI Mempawah, vol. V, no. 1, pp. 19-38, 2017.

[6] Marzuki, "Meneladani Nabi Muhammad Saw. dalam Kehidupan Sehari-hari," Humanika, vol. 8, no. 1, pp. 75-87, 2008.

[7] Hairuddin, "Pendidikan Karakter Berbasis Sunnah Nabi," J. Al-Ulum, vol. 13, no. 1, pp. 167-190, 2013.

[8] M. A. Lubis, "Effective Implementation Of The Integrated Islamic Education," GJAT, vol. 5, no. 1, pp. 59-68, 2015.

[9] S. F. Shah, S. R. Ghazi, S. Shahzad, and I. Ullah, "Quality and Features of Education in the Muslim World," Horiz. Res., 2015a

[10] Iskandar, Tindakan Penelitian Kelas. Jakarta: GP Press, 2011.

[11] Kementerian Agama RI, Petunjuk Teknis Penilaian Pembelajaran Siswa RA. Jakarta: Direktorat Pendidikan Madrasah, 2016.

[12] H. S. Indriati, Metode Gerakan Dalam Menghafal Hadits. Jakarta: Madrasah Terpadu An-Nahl, 2015. 